\title{
ANALISIS KESESUAIAN KEGIATAN WISATA DI KAWASAN PANTAI TANJUNG LESUNG, KABUPATEN PANDEGLANG, BANTEN
}

\author{
Suitability Analysis of Tourism Activities in the Tanjung Lesung Beach, \\ Pandeglang Regency, Banten
}

\section{Tasya Rachmanita, Sahala Hutabarat*) dan Frida Purwanti}

Program Studi Manajemen Sumberdaya Perairan, Departemen Sumberdaya Akuatik Fakultas Perikanan dan Ilmu Kelautan, Universitas Diponegoro

J1. Prof. Sudato, SH, Tembalang, Semarang, Jawa Tengah - 50275, Telp/Fax. +6224 7474698

Email: tasya.rachmanita3@gmail.com

\begin{abstract}
ABSTRAK
Pantai Tanjung Lesung merupakan kawasan wisata pantai yang terletak di desa Tanjung Jaya, Pandeglang. Pantai ini merupakan kawasan dalam proses pengembangan. Tujuan penelitian untuk mengidentifikasi potensi wisata, menganalisa karakteristik dari kegiatan wisata, menganalisa daya dukung kawasan (DDK) dan mengidentifikasi Indeks Keseuaian Wisata (IKW). Penelitian dilakukan pada bulan Juli - September 2016. Metode penelitian yang digunakan adalah metode kuantitatif untuk menghitung IKW dan DDK dan metode deskriptif dengan menyebar kuisioner kepada 30 responden masyarakat dan pengunjung menggunakan teknik sampling purposive sampling untuk mengetahui potensi, persepsi dan daya tarik. Potensi Pantai Tanjung Lesung yaitu memiliki keadaan pasir putih dengan panjang pantai 50 meter. Daya tarik yang diberikan kawasan pantai adalah keindahan pemandangan pantai yang bersih dan masih alami. Vegetasi tumbuhan yang berada di kawasan pantai adalah pohon Kelapa, Gebang dan Trembesi yang digunakan untuk penghijauan lahan dan pelindung dari angin pantai. Indeks Kesesuaian Wisata Pantai Tanjung Lesung dengan di ketiga stasiun termasuk dalam kategori S1 atau sangat sesuai dengan nilai IKW 96\%. Daya Dukung Kawasan pantai Tanjung Lesung untuk kegiatan berenang memiliki daya tampung sebanyak 199 orang, kegiatan snorkeling 90 orang, dan bananaboat 75 orang. Kegiatan wisata pantai tidak melebihi kapasitas DDK. Kesesuaian kegiatan di pantai Tanjung Lesung untuk kegiatan wisata berenang tergolong sangat sesuai dengan nilai IKW 96\% untuk kegiatan snorkeling $70 \%$ dan bananaboat $72 \%$ tergolong sesuai bersyarat karena memiliki kedalaman dan kecerahan yang tidak sesuai dengan ketentuan.
\end{abstract}

Kata Kunci: Potensi Wisata, Indeks Kesesuaian Wisata, Daya Dukung Kawasan, Pantai Tanjung Lesung

\section{ABSTRACT}

Tanjung Lesung beach is a coastal tourist area located in the village of Tanjung Jaya, Pandeglang, that still in development process. The aims were to identify the tourism potentials, to analyse the characteristics of the tourism activities, to analyse carrying capacity (CC) of the area and to identify the Tourism Suitability Index (TSI). The study was conducted from July to September 2016. The research used quantitative method to count TSI and CC and descriptive method by spreading questionnaires to 30 respondents of community and visitors using purposive sampling technique to know the potential, perception and tourism attractiveness. The potency of Tanjung Lesung is full of white sand along of 50 meters. Vegetation in the area of the beach a coconut tree, "Gebang" and "Trembesi" used for reforestation and protection of the wind beach. The attraction of beach area is its beautiful view with clean and unspoiled water. The TSI of Tanjung Lesung Beach in three stations are in S1 category or very suitable with value of 96\%. The CC of Tanjung Lesung Beach for swimming is 199 person, snorkeling is 90 person, and bananaboat is 75 person. Suitability activities in Tanjung Lesung beach for swimming activities is classified as very suitable with TSI value of $96 \%$ for snorkeling activities $70 \%$ and bananaboat $72 \%$ are classified in conditional because of depth and brightness that do not comply with the standard

Keywords: Tourism Potential, Tourism Suitability Index, Carrying Capacity, Tanjung Lesung Beach

*) Penulis penanggung jawab 


\section{PENDAHULUAN}

Pemanfaatan kawasan pantai memberikan dampak yang berbeda baik terhadap sumberdaya alam maupun bagi masyarakat. Salah satu pemanfaatan kawasan pantai adalah untuk kegiatan wisata. Kegiatan wisata pantai dapat memberikan konstribusi yang besar dalam peningkatan pendapatan baik masyarakat maupun pemerintah daerah setempat apabila pengelolaannya dilakukan secara terpadu dan berkelanjutan.

Kawasan Wisata Pantai Tanjung Lesung merupakan salah satu pantai yang di Kabupaten Pandeglang terkenal sebagai kawasan wisata pantai yang indah. Kawasan wisata pantai Tanjung Lesung berada di Desa Tanjung Jaya, Kecamatan Panimbang, Kabupaten Pandeglang, Provinsi Banten. Kawasan wisata pantai memiliki luas \pm 1.500 Ha dengan panjang pantai sepanjang $15 \mathrm{~km}$. Pantai Tanjung Lesung memiliki keindahan pantai berupa pasir putih dan keadaan air pantai yang jernih, gelombang pantai tidak begitu besar karena pantai Tanjung Lesung tidak langsung berdekatan dengan laut lepas. Kegiatan wisata pantai Tanjung Lesung merupakan daya tarik tersendiri untuk wisatawan yang datang ke tempat ini, terdapat kegiatan - kegiatan yang dapat dilakukan yaitu berenang di pinggiran pantai, snorkeling dan bananaboat yang dapat dilakukan di kawasan pantai tersebut. Pantai Tanjung Lesung juga dapat menjadi pilihan saat pantai Carita dan Anyer sudah tidak bisa menampung jumlah wisatawan karena pantai ini memiliki lahan yang sangat luas.

\section{Tujuan}

Tujuan dari penelitian ini adalah:

1. Mengidentifikasi potensi wisata pantai Tanjung Lesung

2. Mengidentifikasi kesesuaian wisata pantai Tanjung Lesung

3. Menganalisa daya dukung kawasan wisata pantai Tanjung Lesung

4. Menganalisa kesesuaian dari kegiatan wisata pantai Tanjung Lesung

\section{MATERI DAN METODE PENELITIAN}

Penelitian dilaksanakan pada bulan Juni sampai bulan September 2016 di Pantai Tanjung Lesung, kawasan wisata pantai Tanjung Lesung berada di sebelah utara dari kabupaten pandeglang.

\section{Alat dan Bahan}

Alat yang digunakan adalah GPS (Global Positioning System), Rollmeter, Secchi disc, tongkat berkala, tongkat berukuran $100 \mathrm{~cm}$, waterpass, bola arus, stopwatch, kamera, dan alat tulis. Bahan yang digunakan meliputi kuisioner dan data sekunder yang didapatkan dari instansi terkait, buku dan jurnal.

\section{Metode}

Metode penelitian yang digunakan adalah metode kuantitatif untuk Indeks Keanekaragaman, IKW dan DDK dan metode deskriptif dengan menyebar kuisioner kepada 30 responden masyarakat dan 30 responden pengunjung menggunakan teknik purposive sampling untuk mengetahui potensi, persepsi dan daya tarik. Persepsi daya tarik wisata pantai Tanjung Lesung dilakukan dengan penilaian terhadap pelayanan, pemandangan pantai, wisata dan kuliner. Wawancara dilakukan dengan panduan kuesioner untuk mengetahui tingkatan persepsi wisatawan yang menggunakan objek wisata pantai sebagai kegiatan rekreasi yang dipilih. Responden diambil sebanyak 30 orang wisatawan berdasarkan kebutuhan tentang apa saja yang berkaitan dengan persepsi daya tarik di pantai Tanjung Lesung.

Kesesuaian Wisata di pantai Tanjung Lesung dilakukan dengan pengukuran dan pengamatan parameter Indeks Kesesuaian Wisata yaitu parameter kedalaman, kecepatan arus, kemiringan pantai, kecerahan, jarak ketersediaan air tawar, tipe pantai, material dasar perairan, penutupan lahan dan biota berbahaya. Titik sampling yang digunakan pada wilayah ini terdapat tiga stasiun. Stasiun pertama berada di bagian barat pantai, stasuin kedua berada di bagian tengah pantai dan stasiun ketiga berada di bagian timur pantai. Pengambilan tiga stasiun ini untuk mengetahui kegunaan lahan pada kawasan pantai tersebut.Penentuan titik pengambilan sampel dilakukan di tiga stasiun di sepanjang pantai di bagian barat, timur dan bagian tengaah pantai.

Pengukuran sampling dilakukan dengan cara pengambilan parameter sesuai dengan matriks Indeks Kesesuaian Wisata (IKW) Pantai adalah dengan pengukuran15 meter ke arah laut dari garis pantai pantai untuk mengetahui, kedalaman pantai, tipe pantai dari pengamatan visual dengan mengamati jenis dan warna pasirnya; lebar pantai dengan pengukuran menggunakan rollmeter, jarak antara vegetasi terakhir yang ada di pantai dengan batas pasang tertinggi; material dasar perairan dengan mengamati bentuk substrat; kecepetan dengan melakukan pengukuran menggunakan bola arus; kemiringan pantai dengan menggunakan tongkat berukuran $100 \mathrm{~cm}$ diletakkan secara horizontal di atas pasir dan di atas kayu diletakkan waterpass, ketinggian dihitung dengan rollmeter kemudian sudut kemiringan $(\alpha)$ didapatkan dari rumus : $\alpha=\arctan \frac{Y}{\mathrm{X}}, \mathrm{Y}$ (jarak antara garis tegak lurus yang dibentuk) dan X (panjang kayu, 100cm); pengukuran tingkat kecerahan perairan dengan menggunakan Secchi disk; penutupan lahan dari pengamatan daerah di sekitar pantai; penentuan biota berbahaya dengan mengamati biota yang ada di sekitar Pantai Tanjung Lesung, dan ketersediaan air tawar dengan mengamati jarak sumber air bersih terdekat dari pantai. 
Analisis kesesuaian wisata menggunakan matriks kesesuaian yang telah diberi penilaian terhadap bobot dan skor maka nilai kesesuaian dihitung berdasarkan total perkalian bobot dan skor semua parameter dengan menggunakan rumus:

Keterangan:

$$
I K W=\Sigma\left[\frac{N i}{\text { maks }}\right] \times 100 \%
$$

$\mathrm{IKW}=$ Indeks Kesesuaian Wisata (\%)

$N i=$ Nilai parameter ke-i (bobot x skor)

$N$ maks $=$ Nilai maksimum dari suatu kategori wisata

(Yulianda,2007)

Daya dukung kawasan dapat diketahui dengan melakukan perhitungan untuk mengetahui potensi ekologis maksimum pengunjung yang menunjukan berapa banyak jumlah wisatawan yang berada di luas area wisata tersebut, luas panjang area yang dapat dimanfaatkan atau luas keseluruhan area yang dimanfaatkan untuk kegiatan di kawasan wisata, unit area untuk kategori tertentu, waktu yang disediakan oleh kawasan untuk kegiatan wisata dalam satu hari, dan waktu yang dihabiskan oleh pengunjung yntuk setiap kegiatan tertentu.

Analisis Daya dukung dihitung dengan persamaan berikut:

\section{Keterangan:}

$$
D D K=K \times \frac{L p}{L t} \times \frac{W t}{W p}
$$

DDK = Daya dukung kawasan

$\mathrm{K}=$ = Potensi ekologis maksimum pengunjung per satuan unit area

$\mathrm{Lp} \quad=$ Luas area atau panjang area yang dapat dimanfaatkan

$\mathrm{Lt}=$ Unit area untuk kategori tertentu

Wt = Waktu yang disediakan oleh kawasan untuk kegiatan wisata dalam satu hari

$\mathrm{Wp}=$ Waktu yang dihabiskan oleh pengunjung untuk setiap kegiatan tertentu (Yulianda, 2007)

Potensi ekologis pengunjung $(\mathrm{K})$ ditentukan oleh kondisi sumber daya dan jenis kegiatan yang akan dikembangkan. Panjang dan luas suatu wilayah yang dapat digunakan oleh pengunjung dipertimbangkan dengan kemampuan alam mentolerir pengunjung mengganggu kelestarian. Jumlah ekologis pengunjung, unit area.

\section{HASIL DAN PEMBAHASAN}

Pantai Tanjung Lesung terletak di Desa Tanjung Jaya, Kecamatan Panimbang, Kabupaten Pandeglang. Secara geografis pantai ini terletak pada $6^{\circ} 21^{\prime}-7^{\circ} 10^{\prime}$ Lintang Selatan dan $105^{\circ} 15^{\prime}-106^{\circ} 11^{\prime}$ Bujur Timur. Perbatasan pantai Tanjung Lesung dari sebelah Utara yaitu Selat Sunda, Selatan yaitu Taman Nasional Ujung Kulon, Barat yaitu Gunung Krakatau, dan dari bagian Timur yaitu Pantai Carita.

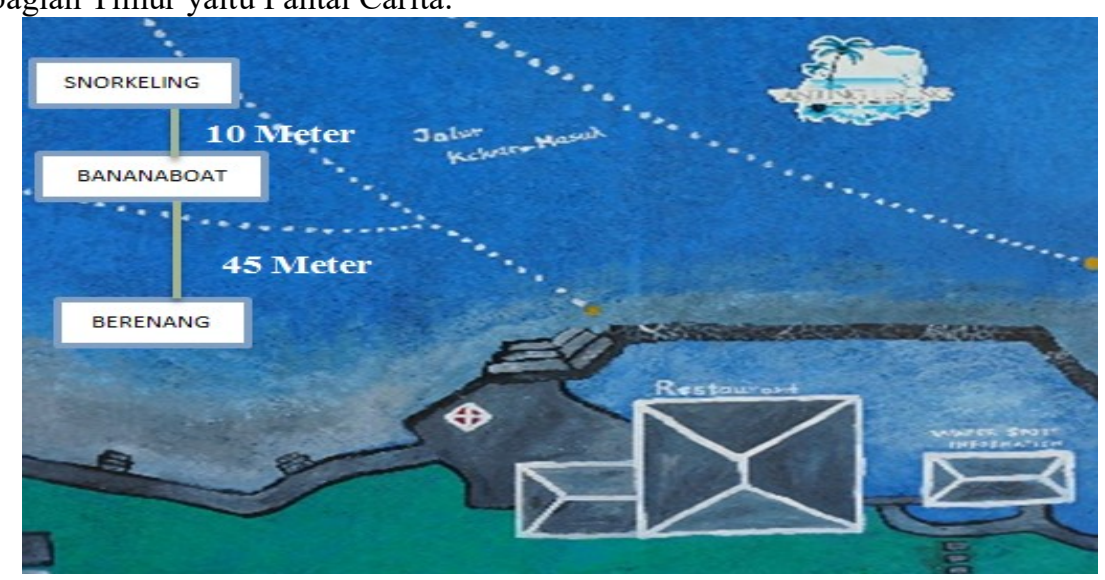

Sumber : Data Pantai Tanjung Lesung (2016)

Potensi pantai Tanjung Lesung memiliki kondisi pantai yang indah dengan pasir yang putih, keadaan air yang jernih menjadikan wisata ini menjadi daya tarik wisatawan yang datang untuk menikmati keindahannya dengan panjang 1,5m untuk kawasan wisata, dengan luasnya panjang pantai ini memberikan rasa nyaman untuk pengunjung karena pantai ini dapat menampung wisatawan yang datang. Pepohonan yang berada di kawasan wisata pantai Tanjung Lesung terdapat pohon Trembesi, pohon Gebang dan pohon Kelapa. Pohon Trembesi sangat melimpah di kawasan pantai Tanjung Lesung dibandingkan pohon Gebang dan pohon Kelapa, karena pohon ini memiliki daun yang rindang sehingga dapat digunakan oleh wisatawan untuk berteduh dan berlindung dari angin pantaiTerdapat beberapa kegiatan permainan di kawasan wisata pantai Tanjung Lesung, oleh karena itu pengelola memberikan Penyediaan fasilitas untuk

\footnotetext{
${ }^{\circ}$ Copyright by Management of Aquatic Resources (MAQUARES)
} 
kegiatan snorkeling seperti pelampung, snorkel, dan fin fish, sedangkan untuk kegiatan bananaboat pengelola pantai menyediakan pelampung dan alat bermain bananaboat.

Hasil wawancara terhadap masyarakat dan wisatawan Pantai Tanjung Lesung mengenai pengelolaan , keindahan, kegiatan wisata yaitu berenang, snorkeling dan bananaboat dan kuliner dengan melihat kondisi bangunan, rasa dan harga dapat dilihat pada Tabel berikut :

Tabel 1. Persepsi Daya Tarik Wisata Pantai Tanjung Lesung

\begin{tabular}{lcccc}
\hline \multirow{2}{*}{ Persepsi } & \multicolumn{4}{c}{ Penilaian (\%) } \\
\cline { 2 - 5 } & TB & CB & B & SB \\
\hline Pelayanan & & 75 & 25 & \\
Pemandangan Pantai & & & & 100 \\
\hline Kegiatan Wisata Wisata & & & \\
\hline Wahana berenang & & & 100 \\
Wahana snorkeling & 10 & 70 & 20 \\
Wahana bananaboat & & 89 & 19 \\
\hline Kuliner & & & \\
\hline Kondisi Fisik & & 10 & 90 \\
Rasa & 40 & 35 & 25 \\
Harga & 80 & 15 & 5 \\
\hline
\end{tabular}

Persepsi para wisatawan terhadap penyediaan fasilitas yang diberikan oleh pantai Tanjung lesung dapat dilihat pada Tabel berikut:

Tabel 2. Penyediaan Fasilitas di Pantai Tanjung Lesung

Keterangan:

\begin{tabular}{|c|c|c|c|c|}
\hline \multirow{2}{*}{ Fasilitas } & \multicolumn{4}{|c|}{ Penilaian (\%) } \\
\hline & TB & CB & B & SB \\
\hline Loket Tiket & & & 75 & 25 \\
\hline Area Parkir & & & & 100 \\
\hline $\begin{array}{l}\text { WC/ Toilet Kamar } \\
\text { Mandi }\end{array}$ & & 10 & 80 & 10 \\
\hline Tempat Ibadah & & & 60 & 40 \\
\hline $\begin{array}{l}\text { Tempat Pembuangan } \\
\text { Sampah }\end{array}$ & & 60 & 25 & 15 \\
\hline Kios/ Warung Makan & & 5 & 80 & 5 \\
\hline
\end{tabular}

TB : Tidak Baik

CB : Cukup Baik

B : Baik

SB : Sangat Baik

Kesesuaian wilayah untuk wisata pantai ditentukan dengan menggunakan Indeks Kesesuaian Wisata (IKW). Hasil perhitungan indeks kesesuaian wisata pantai di kawasan wisata pantai Tanjung Lesung dapat dilihat sebagai berikut:

Tabel 3. Hasil Indeks Kesesuaian Wisata

\begin{tabular}{|c|c|c|c|c|c|c|c|}
\hline \multirow{2}{*}{ No } & \multirow{2}{*}{ Parameter } & \multicolumn{6}{|c|}{ Keterangan } \\
\hline & & Stasiun 1 & BxS & Stasiun 2 & BxS & Stasiun 3 & $\mathbf{B x S}$ \\
\hline 1. & $\begin{array}{l}\text { Kedalaman perairan } \\
\text { (m) }\end{array}$ & 0,75 & 15 & 0,70 & 15 & 0.95 & 15 \\
\hline 2. & Tipe pantai & $\begin{array}{c}\text { Pasir putih } \\
\text { Sedikit karang }\end{array}$ & 10 & Pasir putih & 15 & Pasir putih & 15 \\
\hline 3. & Lebar pantai (m) & 24 & 15 & 19 & 15 & 17 & 15 \\
\hline 4. & Material dasar perairan & Pasir & 9 & Pasir & 9 & Pasir & 9 \\
\hline 5 & Kecepatan rus (m/s) & 0,7 & 9 & 0,9 & 9 & 0,7 & 9 \\
\hline 6. & Kemiringan pantai $\left({ }^{\circ}\right)$ & 3,6 & 9 & 4,2 & 9 & 3,7 & 9 \\
\hline 7 & Kecerahan perairan $(\mathrm{m})$ & 0,40 & 0 & 0,41 & 0 & 0,40 & 0 \\
\hline 8 & Penutupan lahan pantai & $\begin{array}{l}\text { Lahan terbuka, } \\
\text { pohon kelapa }\end{array}$ & 3 & $\begin{array}{l}\text { Lahan terbuka, } \\
\text { pohon kelapa }\end{array}$ & 3 & $\begin{array}{l}\text { Lahan terbuka, } \\
\text { pohon kelapa }\end{array}$ & 3 \\
\hline 9 & Biota berbahaya & Tidak ada & 3 & Tidak ada & 3 & Tidak ada & 3 \\
\hline 10 & Ketersediaan air tawar & 0,75 & 2 & 1,5 & 1 & 1,5 & 1 \\
\hline
\end{tabular}


$(\mathrm{km})$

\begin{tabular}{clll}
$(\mathrm{km})$ & & & \\
\hline Total $\sum(\mathrm{Ni})$ & 80 & 80 & 80 \\
\hline Indeks Kesesuai Wisata (\%) & 96 & 96 & 96 \\
\hline Kriteria & $\mathrm{S} 1$ & $\mathrm{~S} 1$ & $\mathrm{~S} 1$ \\
\hline
\end{tabular}

Berdasarkan hasil pengukuran kedalaman didapatkan pada Stasiun I kedalaman 0,75m, Stasiun II kedalaman pantai $0,70 \mathrm{~m}$ dan pada Stasiun III memiliki kedalaman $0,95 \mathrm{~m}$. Kedalaman pantai Tanjung Lesung termasuk pantai yang dangkal dan sangat sesuai untuk kegiatan wisata seperti berenang dan rekreasi pantai karena kedalaman termasuk kriteria S1 yaitu sangat sesuai dengan kedalaman $0-3 \mathrm{~m}$, hal ini sesuai dengan pendapat Widiatmaka (2007) dalam Yulisa (2016) yang memberikan batasan nilai kedalaman untuk kesesuaian kedalaman ekowisata pantai kategori cukup sesuai antara $3-6$ meter.

Pantai Tanjung Lesung dilihat dari tipe pantainya, terdapat perbedaan di stasiun I dengan tipe pantai pasir putih sedikit karang. Kawasan ini berbeda dengan kawasan stasiun II dan stasiun III yang hanya tedapat pasir putih tanpa karang. Pantai Tanjung Lesung merupakan pantai yang memiliki lebar yang sangat luas, hal ini dapat dilihat dari hasil pengukuran pantai memiliki lebar pada Stasiun I yaitu $24 \mathrm{~m}$, Stasiun II $19 \mathrm{~m}$ dan pada Stasiun III $17 \mathrm{~m}$. Material dasar perairan pada ketiga stasiun yaitu material pasir. Kecepatan arus di kawasan wisata pantai Tanjung Lesung termasuk rendah, ditinjau dari hasil pengukuran keceptan arus didapatkan $0,7 \mathrm{~m} / \mathrm{det}$ pada Stasiun I dan Stasiun III, sedangkan pada stasiun II memiliki kecepatan arus $0,9 \mathrm{~m} / \mathrm{det}$ pada Stasiun II. Berdasarkan kriteria kecepatan arus, arus yang sangat sesuai adalah $0-0,17 \mathrm{~m} / \mathrm{det}$, maka didapatkan kesimpulan bahwa arus di pantai Tanjung Lesung sangat sesuai untuk kegiatan wisata. Pantai Tanjung Lesung merupakan pantai yang landai, dengan kemiringan pantai 3,6 pada Stasiun I, 4, $2^{0}$ pada Stasiun II dan 3,7 pada Stasiun III. Berdasarkan ketentuan kemiringan pantai bahwa pantai Tanjung Lesung memiliki pantai yang sangat sesuai dari kriteria kemiringan pantai, kemiringan pantai yang sesuai unruk wisata pantai adalah kurang dari $10^{\circ}$ (Yulianda, 2007). Kecerahan perairan pantai Tanjung Lesung tergolong cerah walaupun dari hasil pengukuran tidak termasuk pada kriteria kecerahan yang sesuai. Hasil pengukuran kecerahan pada pantai Tanjung Lesung adalah $0,4 \mathrm{~m}$ pada Stasiun I dan Stasiun II dan 0,3 pada Stasiun III.

Pantai Tanjung Lesung memiliki penutupan lahan kriteria terbuka, hasil dari pengamatan pada ketiga stasiun adalah pantai memiliki lahan terbuka karena di sekitar pantai hanya terdapat vegetasi tumbuhan pantai. Berdasarkan kriteria penutupan lahan pantai Tanjung Lesung memiliki kesusaian untuk wilayah wisata, dengan adanya pohon pohon di sekitar pantai menambahkan nilai keindahan tersendiri bagi wisatawan yang berkunjung, hal ini diperkuat oleh Yulis (2016). Biota berbahaya perlu dilakukan untuk mengetahui ada atau tidaknya biota berbahaya yang akan mengangu pengunjung wisata, (Masita, 2013). Biota berbahaya bagi pengunjung wisata diantaranya gastropoda, karang api, landak laut, bulu babi, ubur-ubur, anemon dan ular laut. Pengamatan di sekitar kawasan pantai Tanjung Lesung terhadap biota berbahaya tidak ditemukan adanya biota yang dalam ketegori tersebut pada kawasan wisata.

Ketersediaan air tawar untuk kegiatan wisata di pantai Tanjung Lesung tergolong sangat sesuai, hal ini berdasarkan pengukuran dari jarak pantai hingga adanya fasilitas seperti toilet di kawasan ini dengan jarak yang berbeda pada stasiun I dengan jarak $0,75 \mathrm{~m}$ dari pinggir pantai di bandingkan dengan stasiun II dan III yang memiliki jarak 1m dari pinggir pantai. Menurut Yulis (2013), ketersediaan air merupakan hal penting dalam suatu kehidupan, tidak hanya untuk sektor rumah tangga, melainkan juga untuk sektor wisata.

Ketersediaan air tawar di Pantai Tanjung Lesung sangat memadai untuk kegiatan wisata didalamnya, jarak dari pinggir pantai sampai dengan keberadaan air tawar atau fasilitas air tawar seperti kamar mandi terbilang dekat. Kegiatan wisata untuk ketersediaan air bersih berupa air tawar sangat diperlukan untuk menunjang fasilitas pengelolaan maupun pelayanan wisata. Hal ini juga merupakan menjadi kriteria penilaian terhadap kelayakan prioritas pengembangan wisata pantai (Handayawati, 2010).

Berdasarkan hasil pengukuran dari 3 stasiun menunjukan nilai total skoring pada kriteria pengukuran IKW berdasarkan ketentuan Yulianda (2007) yaitu 96\% pada seluruh stasiun tersebut yang berarti pada kawasan wisata pantai Tanjung Lesung ini sangat sesuai untuk kegiatan wisata karena masuk kedalam kriteria S1 yaitu kawasan ini tidak mempunyai pembatas yang serius untuk menerapkan perlakuan yang diberi pada kegiatan di kawasan wisata.

Hasil pengamatan terhadap daya dukung kawasan di Pantai Tanjung Lesung adalah sebagai berikut:

Tabel 4. Hasil Pengukuran Daya Dukung Kawasan

\begin{tabular}{lccccc}
\hline $\begin{array}{c}\text { Jenis } \\
\text { Kegiatan }\end{array}$ & $\begin{array}{c}\text { Pengunjung } \\
(\mathbf{K}) \text { (orang) }\end{array}$ & $\begin{array}{c}\text { Unit Area } \\
\text { Keseluruhan } \\
(\mathbf{L p})\end{array}$ & $\begin{array}{c}\text { Unit } \\
\text { Area } \\
\text { Kegiatan } \\
(\mathbf{L t})\end{array}$ & $\begin{array}{c}\text { Waktu } \\
\text { pengunjung } \\
\text { / Jam (Wp) }\end{array}$ & $\begin{array}{c}\text { Frekuensi } \\
\text { kunjungan /Jam } \\
\text { dalam satu hari } \\
\text { (Wt) }\end{array}$ \\
\hline $\begin{array}{l}\text { Rekreasi } \\
\text { pantai } / \\
\text { berenang }\end{array}$ & 43 & $5000 \mathrm{~m}$ & $1000 \mathrm{~m}$ & 3 & 13 \\
$\begin{array}{l}\text { Snorkeling } \\
\text { Bananaboat }\end{array}$ & 5 & $5000 \mathrm{~m}$ & $2500 \mathrm{~m}$ & 1 jam & 9 \\
\hline
\end{tabular}

${ }^{\circ}$ Copyright by Management of Aquatic Resources (MAQUARES) 
Pegamatan DDK pada kegiatan berenang dengan luas keseluruhan area didapatkan hasil pengamatan terdapat 23 orang pada unit area keseluruhan yaitu $2500 \mathrm{~m}$ dengan waktu kunjungan untuk kegiatan 3 jam dan jumlah tempat wisata menyediakan waktu selama $13 \mathrm{jam}$ dalam satu hari, dengan ketentuan setiap $50 \mathrm{~m}$ dari luas area hanya untuk 1 pengunjung. Hasil perhitungan DDK didapatkan bahwa pada lahan yang diberikan untuk kegiatan tersebut dapat menampung sebanyak 199 orang untuk melakukan kegiatan wisata berenang di pantai Tanjung Lesung, dan dapat disimpulkan bahwa kawasan pantai Tanjung Lesung memenuhi persyaratan daya tampung untuk kegiatan tersebut.

Kegiatan snorkeling terdapat 5 orang, untuk satu kali permainan diberikan waktu selama satu jam, pada luas lahan $1500 \mathrm{~m}$. Ketentuan kegiatan area per-satu orang pengunjung adalah $500 \mathrm{~m}$ pada jumlah waktu 9 jam dalam satu hari. Hasil pengukuran Daya Dukung Kawasan (DDK) untuk kegiatan snorkeling adalah 90 orang, yang berarti daya tampung untuk kegiatan tersebut tidak melebihi ketentuan yang ada.

Kegiatan bananaboat dalam waktu 20 menit terdapat sebanyak 5 orang pengunjung yang dapat melakukan atraksi tersebut. Berdasarkan hasil DDK daya tampung untuk kegiatan adalah 75 orang pada luas kawasan lahan yang tersedia adalah $1000 \mathrm{~m}$. Berdasarkan kesimpulan tersebut dapat dilihat bahwa kegiatan wisata tersebut di pantai Tanjung Lesung memenuhi syarat karna pengunjung yang melakukan permainan tidak melebihi daya tampung itu sendiri.

Berdasarkan hasil total daya dukung untuk kegiatan berenang, snorkeling dan bananaboat pantai Tanjung Lesung adalah 365 orang pengunjung dengan luas kawasan wilayah baik zona darat maupun perairan adalah $5000 \mathrm{~m}$. Jumlah wisatawan yang datang memenuhi syarat daya dukung kawasan dengan total maksium pengunjung untuk kegiatan seluruhnya. Analisis daya dukung kawasan dapat menjadi pertimbangan untuk pengembangan wisata untuk keberlanjutan kegiatan wisata di pantai Tanjung Lesung tetap terjaga.

Pantai Tanjung Lesung memiliki beberapa kegiatan wisata yaitu berenang, snorkeling dan bananaboat. Kegiatan tersebut telah dibagi pada beberapa wilayahnya tersendiri, untuk kawasan berenang dilakukan dibagian tengah kawasan pantai, wilayah berenang memiliki luas $50 \times 100 \mathrm{~m}$.

Tabel 5. Karakteristik Kegiatan Wisata Berenang

\begin{tabular}{clcccc}
\hline \multirow{2}{*}{ No } & \multicolumn{1}{c}{ Parameter } & \multirow{2}{*}{ Hasil } & \multicolumn{3}{c}{ Keterangan } \\
\cline { 3 - 5 } & & 0,70 & 3 & Skobot & Jumlah \\
\hline 1. & Kedalaman perairan $(\mathrm{m})$ & Pasir putih & 3 & 5 & 15 \\
2. & Tipe pantai & 19 & 3 & 5 & 15 \\
3. & Lebar pantai $(\mathrm{m})$ & Pasir & 3 & 3 & 9 \\
4. & Material dasar perairan & 0,85 & 3 & 3 & 9 \\
5 & Kecepatan arus $(\mathrm{m} / \mathrm{s})$ & 4,2 & 3 & 3 & 9 \\
6. & Kemiringan pantai $\left({ }^{\circ}\right)$ & 0,40 & 0 & 3 & 0 \\
7 & Kecerahan perairan $(\mathrm{m})$ & Lahan terbuka, pohon kelapa & 3 & 1 & 3 \\
8 & Penutupan lahan pantai & Tidak ada & 3 & 3 & 3 \\
9 & Biota berbahaya & 1,5 & 1 & 1 & 1 \\
10 & Ketersediaan air tawar & & & & 80 \\
\hline Total $\sum(\mathrm{km})$ & & & & 96 \\
\hline Indeks Kesesuaian Wisata $(\%)$ & & & & $\mathrm{S} 1$ \\
\hline Kriteria & & & & \\
\hline
\end{tabular}

Kegiatan untuk berenang dilakukan dari pinggir pantai hingga $15 \mathrm{~m}$ ke arah laut, hal ini ditetapkan karena wilayah yang baik dan aman untuk kegiatan tersebut dan berkaitan dengan kedalaman pantai. Pengunjung yang melakukan kegiatan wisata berenang lebih banyak anak kecil hingga anak muda.

Pengukuran kedalaman di kawasan kegiatan wisata berenang menunjukan pantai Tanjung Lesung memiliki kedalaman $0,70 \mathrm{~m}$. Kedalaman ini tergolong aman untuk kegiatan berenang. Tipe pantai untuk kegiatan berenang ini termasuk pada kategori sangat sesuai dengan ketentuan memiliki pasir putih tanpa adanya karang, lumpur dan berbatu. Lebar pantai Tanjung Lesung untuk kegiatan berenang adalah $19 \mathrm{~m}$ pengukuran dilakukan dari pinggir pantai sampai batas vegetasi pohon yang ada di dekat pantai tersebut. Lebar untuk aktifitas berenang dikatakan sangat sesuai karena melebihi kategori diatas $15 \mathrm{~m}$. Material dasar perairan pantai Tanjung Lesung untuk kegiatan berenang adalah pasir, tipe pasir pada material sedimen merupakan sangat sesuai untuk kegiatan wisata berenang.Pantai Tanjung Lesung memiliki kecepatan yang sangat kecil yaitu $0,85 \mathrm{~m} / \mathrm{s}$. Arus yang kecil pada pantai disebabkan karena pantai Tanjung Lesung memiliki lokasi yang menjorok kedalam. Kemiringan pantai di lokasi ini termasuk kedalam kategori landai karena pantai tanjung lesung memiliki kemiringan pantai $4,2^{\circ}$.Pengukuran kecerahan pantai mendapatkan hasil $0,40 \mathrm{~m}$. Hasil pengukuran bahwa pantai ini memiliki kecerahan yang rendah, akan tetapi apabila dilihat dari kedalamannya pantai ini termasuk pantai yang memiliki kecerahan yang baik untuk kegiatan wisata berenang.

Berdasarkan pengamatan secara visual pada penutupan lahan dan biota berbahaya dari wisata berenang di pantai Tanjung Lesung adalah lahan terbuka dan tidak adanya biota berbahaya di sekitar lokasi berenang di pantai ini. Terdapat beberapa pohon-pohon Kelapa, dan pohon Trembesi di sekitar pantai, sedangkan biota berbahaya tidak ada di lokasi berenang. Ketersediaan air tawar di pantai Tanjung Lesung berjarak $1,5 \mathrm{~m}$, berdasarkan pengukuran pada lokasi 
tersebut menyatakan bahwa kurang baik. Menurut ketentuan ketersediaan air tawar pada lokasi pantai bahwa lokasi yang baik adalah $0,2 \mathrm{~km}$ dari lokasi pantai. Ketersediaan air tawar berada pada fasilitas kamar mandi di pantai ini dan pengukuran dilakukan jarak dari pinggir pantai sampai dengan lokasi kamar mandi.

Hasil pengukuran untuk kriteria kesesuaian unruk kegiatan wisata snorkeling adalah sebagai berikut:

Tabel 6. Kegiatan Wisata Snorkeling

\begin{tabular}{lcccc}
\hline \multirow{2}{*}{ Parameter } & \multirow{2}{*}{ Hasil } & \multicolumn{3}{c}{ Penilaian } \\
\cline { 3 - 5 } & & Bobot & Skor & Jumlah \\
\hline Kecerahan perairan (\%) & 100 & 5 & 2 & 10 \\
Kecepatan Arus (cm/det) & 0,3 & 1 & 3 & 3 \\
Lebar hamparan datar karang $(\mathrm{m})$ & 580 & 1 & 3 & 3 \\
Kedalaman (m) & 6 & 1 & 3 & 3 \\
Tutupan komnunitas karang $(\%) *)$ & 40 & 5 & 1 & 5 \\
Jenia Life Form *) & 7 & 3 & 1 & 3 \\
Jenis Ikan Karang *) & 167 & 3 & 3 & 9 \\
\hline Total & & & & 36 \\
\hline IKW & & & & 80 \\
\hline Kriteria & & & \\
\hline
\end{tabular}

*) Sumber : Maulina (2009).

Hasil pengukuran yang dilakukan pada kecerahan di area kegiatan snorkeling adalah $90 \%$, pada pengukuran kecerahan ini didapatkan hasil $92 \mathrm{~m}$. Berdasarkan hasil pengukuran kecerahan pantai dapat dikategorikan bahwa kecerahan termasuk pada kriteria sesuai dan bersyarat yaitu kecerahan pantai termasuk pada 80m sampai dengan 100m.Area untuk kegitan snorkeling di pantai Tanjung Lesung memiliki arus yang kecil yaitu $0,3 \mathrm{~cm} / \mathrm{det}$ dan termasuk kecepatan arus termasuk pada kategori sangat sesuai. Hasil pengamatan pada lebar hamparan datar karang di area kegiatan snorkeling adalah $580 \mathrm{~m}$. Lebar hamparan karang pada area yang termasuk kategori sangat sesuai untuk kegiatan adalah lebih dari 500m, hal tersebut telah ditentukan berdasarkan ketentuan

Kesesuaian kegiatan wisata untuk kegiatan wahana bermain bananaboat terdapat kriteria tertentu, hasil pengukuran kesesuaian kegiatan bermain bananaboat terdapat pada tabel dibawah ini.

Hasil data jenis life form di kawasan wisata Snorkeling adalah 7 jenis yaitu, acropora branching, acropora tabulate, coral encrusting, coral foliose, coral mushroom, coral branching, dan coral submassive. Jenis lifeform di kawasan snorkeling termasuk kurang sesuai. Menurut ketentuan jenis lifeform yang sesuai adalah 12 jenis. Jenis ikan karang di kawasan Snorkeling adalah 167 jenis, hal ini menunjukan dari ketentuan jenis ikan karang di kawasan ini termasuk sangat sesuai dengan ketentuan untuk wilayah snorkeling jenis ikan karang memiliki 50 jenis ikan karang Maulina (2009).

Tabel 7. Kegiatann Wisata Bananaboat

\begin{tabular}{lcccc}
\hline \multirow{2}{*}{ Parameter } & \multirow{2}{*}{ Hasil } & \multicolumn{3}{c}{ Penilaian } \\
\cline { 3 - 5 } & 6 & Bobot & Skor & Jumlah \\
\hline Kedalaman $(\mathrm{m})$ & 0,11 & 3 & 2 & 10 \\
Kecepatan Arus(m/det) & & & & 9 \\
\hline Total & & & & 19 \\
\hline IKW & & & S2 \\
\hline Kriteria
\end{tabular}

Kesesuaian kegiatan wisata bananaboat dilihat dari parameter kedalaman dan kecepatan arus. Hasil pengukuran pada kedalaman wisata bananaboat adalah $6 \mathrm{~m}$, berdasarkan ketentuan wisata bahwa pantai memiliki kategori sesuai bersyarat yaitu pantai baik untuk kegiatan bananaboat akan tetapi terdapat beberapa persyaratan yang berkaitan dengan kedalaman pantai tersebut.

Kecepatan arus pada area bananaboat memiliki arus yang kecil, dapat dilihat dari hasil pengukuran kecepatan arus di area ini adalah $0,11 \mathrm{~m} /$ det. Menurut Yulianda (2007), kesesuaian arus pantai untuk kegiatan wisata bananaboat adalah $0-0,15 \mathrm{~m} / \mathrm{det}$. Hasil pengukuran dapat disimpulkan bahwa arus pantai yang di gunakan untuk area merupakan kategori sangat sesuai.

Total nilai pengukuran parameter kedalaman dan kecepatan arus di area bananaboat adalah 19, dari hasil perhitungan menggunakan rumus IKW adalah $76 \%$. Hasil pengukuran merupakan kategori sesuai bersyarat yaitu kawasan pantai pada kegiatan bananaboat tergolong sesuai akan tetapi terdapat pembatasan untuk mempertahankan tingkat perlakuan pada lokasi ini yang harus diterapkan. 


\section{KESIMPULAN}

Kesimpulan yang didapat pada penelitian ini adalah sebagai berikut:

1. Potensi Pantai Tanjung Lesung yaitu memiliki keadaan pasir putih dengan panjang pantai 50 meter. Daya tarik yang diberikan kawasan pantai adalah keindahan pemandangan pantai yang bersih dan masih alami. Vegetasi tumbuhan yang berada di kawasan pantai yaitu pohon Kelapa, pohon Gebang dan Trembesi yang digunakan untuk penghijauan lahan dan pelindung dari angina pantai.

2. Kesesuaian Wisata Pantai Tanjung Lesung dengan di ketiga stasiun termasuk dalam kategori S1 atau sangat sesuai dengan nilai IKW 96\%

3. Daya Dukung Kawasan pantai Tanjung Lesung untuk kegiatan berenang memiliki daya tampung sebanyak 199 orang, kegiatan snorkeling 90 orang, dan bananaboat 75 orang. Kegiatan wisata pantai tidak melebihi kapasitas DDK.

4. Kesesuaian kegiatan di pantai Tanjung Lesung untuk kegiatan wisata berenang tergolong sangat sesuai dengan nilai IKW 96\%, untuk kegiatan snorkeling 70\% dan bananaboat $72 \%$ tergolong sesuai bersyarat karena memiliki kedalaman dan kecerahan yang tidak sesuai dengan ketentuan.

\section{UCAPAN TERIMAKASIH}

Penulis mengucapkan terimakasih kepada rekan yang membantu saat dilaksankannya penyusunan penulisan skripsi ini, kepada masyarakat, pengelola, dan instansi di pantai Tanjung Lesung Kabupaten Pandeglang Banten, dan kepada dosen penguji Prof. Dr. Ir. Supriharyono, M.S., Prof. Dr. Ir. Djoko Suprapto, M.Sc., dan Ir. Siti Rudiyanti, M.Si.

\section{DAFTAR PUSTAKA}

Armos, N. H. 2013. Studi Kesesuaian Lahan Pantai Wisata Boe Desa Mappakalompo Kecamatan Galesong Ditinjau Berdasarkan Biogeofisik.[Skrpsi].Fakultas Ilmu Kelautan dan Perikanan. Universitas Hasanuddin. Makassar.

Handayani, O. 2010. Kajian Sumberdaya Pesisir untuk Pengembangan Wisata Pantai Cerocok Painan, Kabupaten Pesisir Selatan Sumatera Barat. [Skripsi]. Departemen Manajemen Sumberdaya Perairan . Fakultas Perikanan dan Ilmu Kelauan. Institut Pertanian Bogor. Bogor.

Haris, A. 2003. Analisis Kesesuaian Lahan dan Kebijakan Pemanfataan Ruang Wilayah Pesisir Teluk Kayeli Kabupaten Buru. [Tesis]. Program Pascasarjana IPB. Bogor. $54 \mathrm{hlm}$.

Maulina, T. 2009. Pengaruh Proses Biorock terhadap Struktur Komunitas Ikan Karang pada Terumbu Buatan di Tanjung Lesung, Banten. Fakultas Perikanan dan Ilmu Kelautan IPB. Bogor.

Sunarto, 1991. Geomorfologi Pantai: Kursus Singkat Pengelolaan dan Perencanaan Bangunan Pantai. Pusat Antar Universitas Ilmu Teknik UGM. Yogyakarta.

Yulianda, F. 2007. Ekowisata Bahari Sebagai Alternatif Pemanfaatan Sumberdaya Pesisir Berbasis Konservasi. [Makalah] Departemen Manajemen Sumberdaya Perairan. Institut Pertanian Bogor.

Yulisa. E.N. Y. Johan. dan D. hartono. 2013. Analisis Kesesuaian dan Daya Dukung Ekowisata Pantai Kategori Rekreasi Pantai Laguna Desa Merpas Kabupaten Kaur. Bengkulu. Vol.1. No:1 